\title{
Certain Aspects of Nutritional Security of People with Gluten-Related Disorders
}

\author{
Rodica Siminiuc ${ }^{1,2 *}$, Dinu Țurcanu ${ }^{2,3}$ \\ ${ }^{1}$ Food and Nutrition Department, Chisinau, Republic of Moldova \\ ${ }^{2}$ Technical University of Moldova, Chisinau, Republic of Moldova \\ ${ }^{3}$ Informatization, Partnerships, Institutional Image and Communication Office, Chisinau, Republic of Moldova \\ Email: ^rodica.siminiuc@adm.utm.md, dinu.turcanu@adm.utm.md
}

How to cite this paper: Siminiuc, R. and T,urcanu, D. (2020) Certain Aspects of Nutritional Security of People with Gluten-Related Disorders. Food and Nutrition Sciences, 11, 1012-1031.

https://doi.org/10.4236/fns.2020.1111072

Received: October 23, 2020

Accepted: November 24, 2020

Published: November 27, 2020

Copyright (c) 2020 by author(s) and Scientific Research Publishing Inc. This work is licensed under the Creative Commons Attribution International License (CC BY 4.0).

http://creativecommons.org/licenses/by/4.0/

\section{(c) (i) Open Access}

\begin{abstract}
As a consequence of the production of high-yielding cereal varieties per hectare and the considerable increase in gluten consumption, today, consequently, we face a rising epidemic of disorders related to gluten consumption: celiac disease, gluten allergy gluten sensitivity. Nutritional therapy is the only treatment for celiac disease unanimously accepted by the medical community. The aim of the study is to analyze the food and nutritional security of people with disorders related to gluten consumption from the perspective of assessing the nutritional deficiencies of people diagnosed with celiac disease or gluten intolerance, but also assessing the nutritional deficiencies of gluten-free products. The study on the assessment of nutritional deficiencies of people with disorders related to gluten consumption, but also the nutritional deficiencies of gluten-free products/diets were conducted on the PubMed search engine. 154 free full text papers published in the period 2010-2020 were analyzed, according to the keywords (gluten free, diet, deficiencies). Specialists in the field are unanimous in the opinion that increasing nutritional security and ensuring sustainability can be achieved by: diversifying gluten-free products; extension of legislation to strengthen gluten-free products; developing educational strategies focused on the relationship between nutrients, food and human health; informing the population and optimizing services in order to increase the quality of life and health. However, the design of GF products, both technologically and nutritionally, especially bakery/pastry, pasta is still a challenge, and research in this area, is current and required.
\end{abstract}

\section{Keywords}

Gluten Free Diet, Nutritional Deficiencies, Nutritional Security, Cereals, Food Education 


\section{Introduction}

Globally, cereals hold the first place after the areas occupied by agricultural land. Thus, 55\% of the world's agricultural land, or about 720 billion hectares, belongs to cereals. World cereal production now stands at 2762 million tons [1], of which only wheat accounts for $28 \%$, rice and maize for $25 \%$, and the rest for barley, oats, rye, sorghum and millet. The production of high-yield, disease-resistant cereal varieties per hectare, including semi-dwarf wheat, has led, respectively, to a considerable increase in gluten consumption, due to its properties for improving the organoleptic indices of the products. Consequently, today, we are facing a rising epidemic of gluten-related disorders (Figure 1) [2] [3].

\subsection{Celiac Disease}

Celiac disease (CD) is a unique disease in its own way, being at the same time a food intolerance and an autoimmune pathology triggered by gluten ingestion. It is a form of enteropathy, which affects the small intestine of genetically predisposed people. It develops as a result of the combination of environmental factors (gluten) and autoantigens (tissue enzyme transglutaminase-tTG). As a result, the inflammatory processes of the small intestine are followed by the flattening of the intestinal villi and, subsequently, the reduction of the intestinal surface area of absorption and malnutrition [5]. The first mentions of celiac disease dated back to about 10,000 years ago, when barley and wheat began to play an important role in human nutrition [3], but the link with gluten was defined only in the last century and the spread of the disease was due to industrial production of wheat and its increase in industrial consumption. In 1970, the European Society of Pediatric Gastroenterology and Nutrition (ESPGAN) defined celiac disease as a permanent intolerance to gluten [6] [7]. In the past it was considered a rare disease, prevalent in childhood and with classic manifestations of malabsorption syndrome. Epidemiological studies based on new antibody tests have shown that

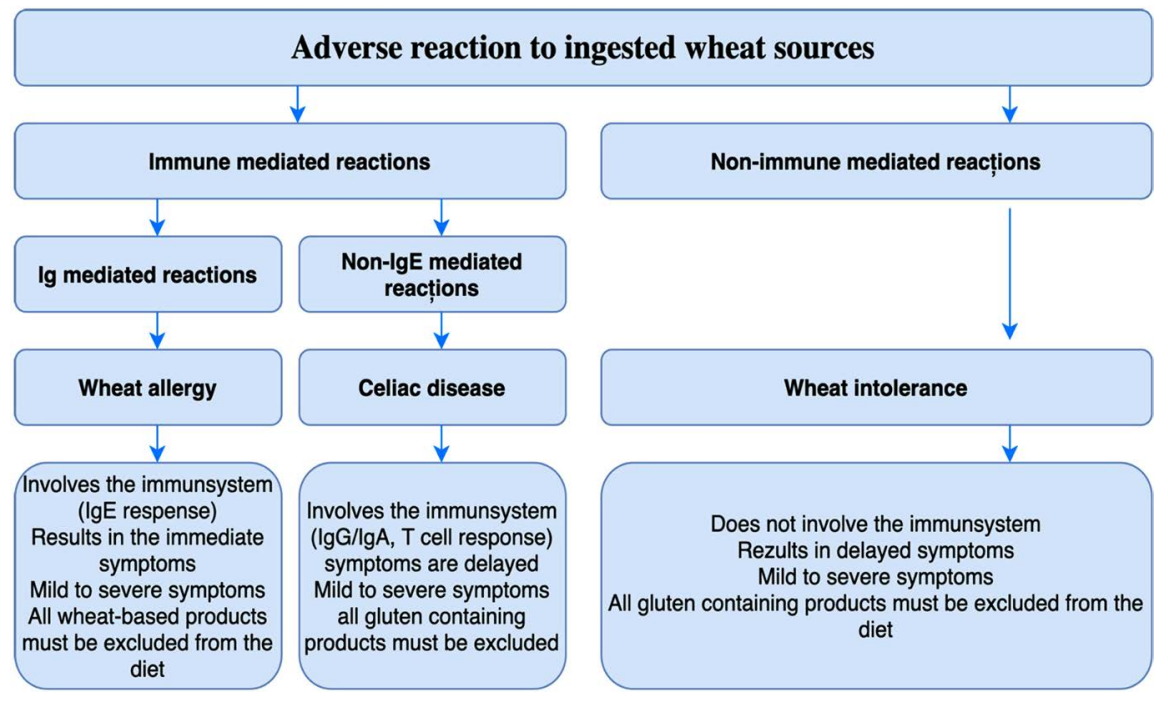

Figure 1. Adverse reactions to ingested wheat source [4]. 
adults are more and more frequently diagnosed, with an average age of about 45 years and about $20 \%$ of those diagnosed over 60 years [5] [8] [9]. The disease is more prevalent in women, with a male/female ratio of 1:2.5. Celiac disease can affect any organ or system, with a wide range of clinical manifestations of varying severity [10].

Representing a major cause of malabsorption syndrome, and one not negligible in our geographical area, celiac disease has polarized the attention of researchers. Although the term celiac disease is currently the most widespread, many synonyms remain in circulation: gluten enteropathy, Gee-Thaysen's disease, idiopathic steatorrhea, netropical sprue or celiac syndrome. The incidence of celiac disease in the world is 6,334,993 people and about 1\% of Europe's population suffers from celiac disease [11] (Figure 2). The difficulty of diagnosis makes it almost impossible to create a real statistical database on this disease [12].

The prevalence of celiac disease is highest in the Saharawi (a town in Africa), followed by Turkey (1:77). Some bibliographic sources indicate the prevalence of celiac disease of $2.22 \%$ in Romania, with equal distribution between sexes and the predominance of patients in urban areas aged between 30 - 60 years. The prevalence of celiac disease in the world and in Europe is shown in Table 1 [5] [11] [13].

Table 1. Incidence of celiac disease [5] [11] [13].

\begin{tabular}{ccccc}
\hline \multirow{2}{*}{ Parts of the world } & The country & Incidence & Europa & Incidence \\
\cline { 1 - 3 } Africa & Saharawi & $1: 18$ & & \\
& Burkina Faso (Mossi) & $1: 600$ & & \\
America & Argentine & $1: 167$ & Hungary & $1: 85$ \\
& Brazil & $1: 681$ & Estonia & $1: 88$ \\
& U.S.A. & $1: 133$ & Finland & $1: 99$ \\
Asia & Iran & $1: 166$ & UK & $1: 100$ \\
& Israel & $1: 157$ & Italy & $1: 106$ \\
& Turkey & $1: 77$ & & $1: 122$ \\
Australia & Western Australia & $1: 430$ & & \\
\hline
\end{tabular}

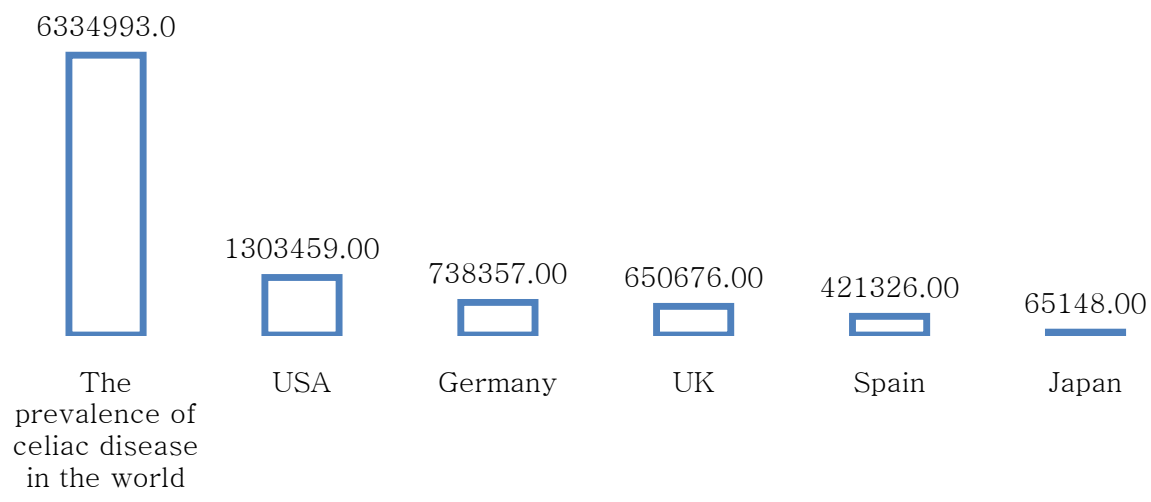

Figure 2. Prevalence of celiac disease in the world (number of people) [11]. 


\subsection{Gluten}

The pathogenesis of celiac disease involves genetic, environmental and immunological factors. Celiac disease is caused by the improper reaction of T-helper lymphocytes to the gluten contained in the food consumed. The primary symptoms of celiac disease are manifested by histological disorders in the mucosa of the duodenal tract and by an immunological reaction of the laminae. Initially, the damage is cellular, and the cells involved are T-helper lymphocytes [14] [15] [16]. Multiple studies targeting the immune response to gluten have shown that gliadin, the alcohol-soluble glycoprotein fraction of gluten, is responsible for the adverse reaction to gluten. Gliadin peptides were classified into:

- Toxic, capable of causing tissue damage to the intestinal mucosa, independent of the activation of T-helper lymphocytes which explains their activity by activating the innate immune response.

- Immunogenic, able to specifically stimulate the cell lines of HLA-DQ2/DQ8 T lymphocytes and B lymphocytes and, respectively, to activate the acquired immune response [17].

Gliadins are difficult to digest due to their chemical complexity. From the partial digestion of glutamine and proline, fragments capable of revoking an inflammatory response with the destruction of intestinal epithelial cells are obtained [5]. 4 fractions of prolamins were identified: $\alpha-, \beta-, \gamma$ - and $\omega$ according to their electrophoretic mobility in acidic environment [18].

The $\alpha$ form, with a portion of 266 amino acids, called $\alpha$-gliadin, is considered to contain the most active epitopes for the immune system and appears to be primarily responsible for toxicity. Fragment 31 - 43 of A-gliadin is transported through the mucosa of celiac patients in twice as large quantities compared to the same process in healthy individuals and has no immunological activity against T-helper lymphocytes [19] (Figure 3).

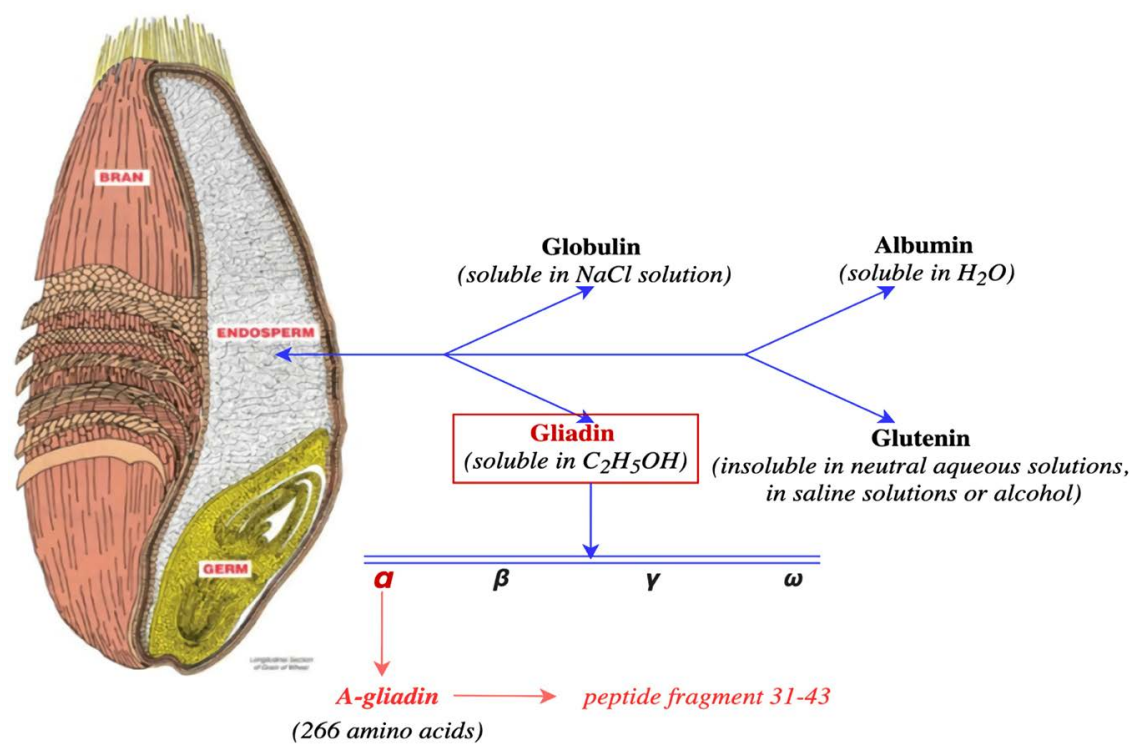

Figure 3. Protein fractions of cereals and subfractions of gliadin [18] [19]. 
Under normal conditions, gliadin is degraded in intestinal endothelial cells into small non-immunogenic peptide fragments. But when particular complications occur that intervene with some mechanisms responsible for the passage into the intestinal lumen, gliadin can easily bypass endothelial cells-zonulin (a newly discovered peptide), the secretion of which can be stimulated by numerous pathological events and which is able to trigger, through a receptor binding, an increase in intestinal permeability caused by changes in the cytoskeleton of enterocytes. In the submucosa of a large number of allergens and gliadin [16] [20] [21].

\subsection{Gluten Allergy}

Wheat food allergy is a reaction usually mediated by allergic IgE-antibodies (immunoglobulin E) produced in large quantities by the immune system each time allergenic foods are consumed, and as a result, after a series of processes, causes the production histamine that causes inflammation. It differs from celiac disease in that in the latter we have an immune response to gluten consumption related not to antibodies, but to cells [4] [22]. The patient's first contact with gluten does not lead to a negative reaction, but the immune system selects it as a "bad" substance, recording it and memorizing it in a process called sensitization. Over time, the immune system becomes increasingly sensitive and initiates the production of large amounts of IgE, which binds to mast cells, inducing the release of histamines [23]. Allergy has different symptoms depending on the subject. Symptoms of gluten allergy can occur immediately after eating gluten-free foods. Affected patients have similar manifestations to other food allergies, with skin symptoms (dermatitis, eczema, hives), respiratory (asthma or allergic rhinitis) and gastrointestinal tract (inflammation of the lips and tongue). It is important to note that the damage caused by gluten on the gastrointestinal tract in cases of allergy is not permanent and passes with the overcoming of the acute phase [3].

\subsection{Gluten Sensitivity}

The results of a major international study, conducted by the University of Maryland School of Medicine in Baltimore (USA) in collaboration with the University of Naples (Italy), were recently published in the scientific journal BMC Medicine, identifying the differences between celiac disease and susceptibility to gluten [24]. While celiac disease is activated by an autoimmune mechanism, largely determined by the immune system's adaptive reaction, gluten sensitivity is triggered by an immune mechanism that does not interfere with the functionality of the intestinal barrier. Gluten sensitivity was defined as gluten intolerance in which, unlike celiac disease and gluten allergy, a normal epithelium was found following an intestinal biopsy. It is characterized by symptoms similar to those of irritated bowel (abdominal pain and bloating, diarrhea) and extraintestinal symptoms with neurological prevalence, which manifests itself immediately after 
eating gluten. It is more common in adults than in children. About 17 million Americans suffer from gluten sensitivity, with a six-fold higher prevalence of celiac disease [10] [25].

\subsection{Purpose of the Study}

The aim of the study is to analyze the food and nutritional security of people with disorders related to gluten consumption from the perspective of assessing the nutritional deficiencies of people diagnosed with $\mathrm{CD}$ or gluten intolerance, but also assessing the nutritional deficiencies of gluten-free products (GFP).

\section{Working Procedure}

The study on the assessment of nutritional deficiencies of people with disorders related to gluten consumption, but also the nutritional values of GFP/diets were conducted on the PubMed search engine. Initially, 5995 works were selected, which include the keywords "gluten free and diet (GFD)", which spanned a period from 1951-2020. Subsequently, the time interval was reduced and, respectively, for the years 2000-2020, 4655 works were selected. The addition of the keyword "deficiencies" reduced the number of works to 622 for the period 2010-2020. Of these, only 154 were full text (Figure 4). The respective works

Total articles: 5995

period: 2020-....

keywords: gluten free, diet

Total articles: 4755

period: 2020-2000

keywords: gluten free, diet

Total articles: 622

period: 2020-2010

keywords: gluten free, diet, deficiencies

Total articles: 3423

period: 2020-2000

keywords: gluten free, diet, deficiencies
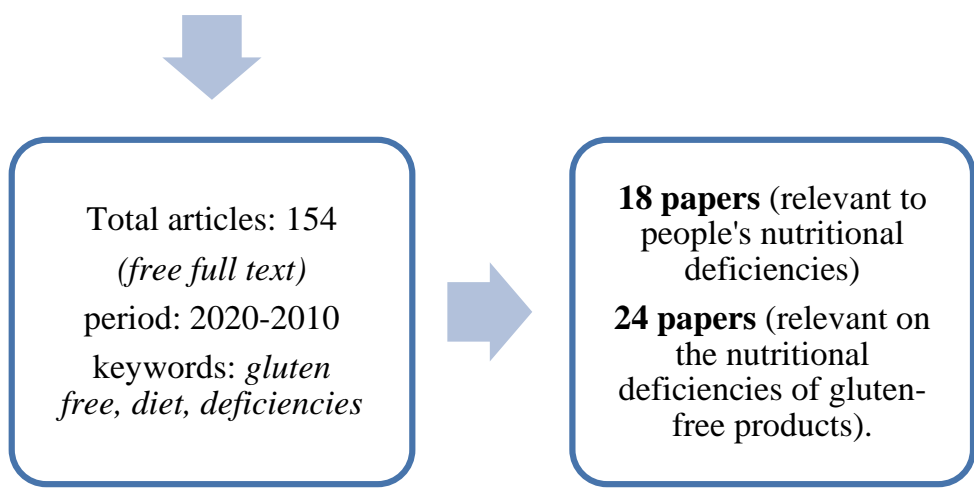

Figure 4. Study design. 
were analyzed and the information was selected depending on their belonging to the nutritional deficiencies of people with disorders related to gluten consumption or to the deficiencies identified in GFP/GFD. Of these, 18 papers were found relevant on the nutritional deficiencies of people and 24 papers were relevant on the nutritional deficiencies of GFP/GFD.

\section{Nutritional Safety of People with Gluten-Related Disorders}

Nutritional therapy is the only treatment for celiac disease unanimously accepted by the medical community and consists of a rigorous gluten-free diet. The adoption of a gluten-free diet causes a gradual normalization of the intestinal mucosa, the disappearance of antibodies presents in the acute phase (anti-transglutaminase antibodies) and any symptoms present before diagnosis. The gluten-free diet must be strict and followed for life, especially in celiac disease [2] [26].

\subsection{Nutritional Status}

Numerous studies have reported that celiac disease has a major impact on the nutritional status of celiac disease at the time of diagnosis and in the pre-diagnosis period. At the time of diagnosis of celiac disease, a transient lactose intolerance, secondary to celiac enteropathy, can be observed. This can cause a tendency to diarrhea, flatulence and persistent abdominal pain, which is why it may be advisable to reduce or omit (during the initial treatment period) the daily intake of lactose, substituting whole milk with low-lactose milk. It is not mandatory to exclude other products such as yogurt or cheese, which have a low content of these carbohydrates. After 3 - 6 months of GFD, the level of intestinal lactase tends to normalize and there is the possibility of reintroducing lactose-containing products into the diet. At diagnosis, depending on the time elapsed since the onset of celiac disease and/or the length of the affected gastrointestinal tract, and/or various levels of malabsorption, a deteriorated nutritional status occurs [27] [28]. In newly diagnosed, iron deficiency, vitamin B12, folate is frequently found [29] [30].

Lipid malabsorption, carbohydrate and vitamin deficiencies (A, D, E, K) were encountered in cases when the intestinal mucosa was severely affected [31]. In some patients there was an increase in alkaline phosphatase, changes in bone mineral density, osteoporosis, osteopenia, depressive disorders [32] [33] [34]. These nutritional deficiencies largely disappear after the initiation of an agglutinative regime, due to the restoration of the integrity of the intestinal mucosa and the villi responsible for the absorption of nutrients. It has been pointed out that, from an initial malnutrition status (deficiencies), some patients may develop an excess malnutrition status due to the consumption of products high in saturated fats, simple sugars and salt. A paradox is currently occurring: in celiac, a rigorous gluten-free diet can become a risk factor for chronic diseases such as cardiovascular disease, obesity, diabetes and cancer [35] [36] (Table 2). 
Table 2. Nutritional deficiencies of people with gluten-related disorders.

\begin{tabular}{|c|c|c|c|c|}
\hline Authors & $\begin{array}{l}\text { Publication } \\
\text { of the paper }\end{array}$ & Target people & Nutritional deficiencies & Remark/recommendations \\
\hline [37] & 2020 & - & $\mathrm{Fe}$ & Remarks: anemia \\
\hline [38] & 2019 & children/adults & Fe, Folic acid, Vit.B12 & \\
\hline [39] & 2019 & & $\mathrm{Fe}, \mathrm{Zn}, \mathrm{Cu}, \mathrm{Ca}$, Fiber, Cr, Vit. D, Folic acid, B12 & \\
\hline [40] & 2019 & $\begin{array}{l}\text { children/adolescents } \\
\quad(4-18 \text { years })\end{array}$ & Vit D (not necessarily due to malabsorption) & $\begin{array}{l}\text { Remarks: alkaline phosphatase activity; } \\
\text { reduction of bone mineral density }\end{array}$ \\
\hline [41] & 2019 & children & $\mathrm{Fe}, \mathrm{Ca}$, vit $\mathrm{D}$, fiber. & $\begin{array}{l}\text { Recommendations: food education, consumption } \\
\text { of local fortified products, pseudo-cereals etc. }\end{array}$ \\
\hline [42] & 2019 & children (over 2 years) & $\mathrm{B} 12, \mathrm{Fe}, \mathrm{Ca}, \mathrm{Mg}, \mathrm{Zn}$, Folic acid, vit. D. & \\
\hline [43] & 2018 & adults & $\mathrm{Ca}, \mathrm{Fe}, \mathrm{Mg}, \mathrm{Zn}$. & \\
\hline [33] & 2018 & & $\mathrm{Fe}, \mathrm{B} 12$, Folic acid & Remarks: Osteoporosis, osteopenia \\
\hline [44] & 2017 & children & Only $7 \%$ - Fe deficiency & \\
\hline$[32]$ & 2015 & adults & Vitamin B12-deficiency, Folic acid & \\
\hline [45] & 2015 & & $\mathrm{Fe}$ & \\
\hline [34] & 2015 & adults & $\begin{array}{l}\text { Low protein content (serum tyrosine, } \\
\text { phenylalanine and tryptophan concentrations, } \\
\text { respectively). }\end{array}$ & $\begin{array}{l}\text { Remarks: In the group of patients with } C D \text {, the } \\
\text { presence of major depressive disorder }(n=42) \\
\text { was not associated with the intake or serum } \\
\text { levels of essential amino acids. }\end{array}$ \\
\hline [18] & 2014 & & Mineral elements & $\begin{array}{l}\text { Recommendations: Nutritional balance of GFD. } \\
\text { Development of educational strategies based on } \\
\text { the relationship between nutrients, food and } \\
\text { human health to optimize the therapeutic } \\
\text { approach in celiac patients. }\end{array}$ \\
\hline [35] & 2014 & $\begin{array}{l}\text { adult CD-patients } \\
\text { (in the Netherlands) }\end{array}$ & Vit. A, B6, Zn, Fe. & Remarks: Malnutrition/overweight in some \\
\hline [46] & 2011 & & Fe, vit. B12, D & \\
\hline [47] & 2011 & $\begin{array}{l}\text { Women } / \text { men } \\
54 \text { years old }\end{array}$ & $\mathrm{Fe}$ & \\
\hline [30] & 2010 & - & $\begin{array}{l}\mathrm{Fe}, \mathrm{Ca}, \mathrm{P} \text {, folate, thiamine, niacin, riboflavin, } \\
\text { vit.D, fiber }\end{array}$ & $\begin{array}{l}\text { Recommendations: Use in GFD of minor cereals } \\
\text { and pseudo-cereals, legumes for nutritional } \\
\text { balancing of GF products. }\end{array}$ \\
\hline
\end{tabular}

\subsection{The Gluten-Free Products Market}

The international market offers consumers, who follow a GFD, a wide range of products: bread and bakery products, pasta, pancakes, dumplings, pickles, biscuits, wafers, sauces, beer etc. Public catering establishments in Italy, for example, offers people with gluten-related disorders gluten-free meals, and the state provides celiacs with monthly monetary rewards. 3.2. The gluten-free products market. In the Russian Federation, following research, technologies have been developed for obtaining pasta based on mixtures of buckwheat, corn and rice flour, using the methods of mixing and pressing the dough with a humidity of $34 \%-38 \%$ and the temperature at the end. turbulence of $74^{\circ} \mathrm{C}-78^{\circ} \mathrm{C}$. 
The global gluten-free market has grown considerably in recent decades not only because of the growing number of celiac patients (due to early and more accurate diagnosis), but also because of the increased demand from non-celiac patients, because it is believed that gluten-free products can help relieve and treat disorders such as autism, chronic fatigue, schizophrenia, attention deficit disorders, multiple sclerosis, migraines and fertility problems. Moreover, thanks to celebrities, who have adopted and promoted a GFD, it has become known, has been taken over and included as a lifestyle by many people. As a result of the growing market, companies are expanding their offer with a large number of snacks and beverages designed to attract consumers on a sensory level. Over the last decade, scientific research has come with more and more information about gluten-free ingredients, which has allowed manufacturers to innovate using alternative cereals and new ingredients.

The GFP market grew at an average annual rate of $28 \%$ in 2004, when it was valued at $\$ 580$ million, then in 2008 , at $\$ 1.56$ billion, and is estimated to reach 2.5 in 2012. billion dollars. In reality, this rate was reached in 2010, and in 2012 it reached 4.2 billion euros (for an annual growth rate of 28\%). In 2019, the market for gluten-free products in the US was estimated at USD 21.61 billion, and in 2020 it was estimated at only 5.6 billion (Figure 5).

The COVID-19 pandemic has affected the global market, including gluten-free products. Due to the limited activities of the supply chain, producers are not able to procure raw materials and manufacture goods to meet demand [50]. However, after the pandemic, the market for gluten-free products is expected to show an optimistic upward trend, due to increasing consumer demand, due to a change in lifestyle, towards a healthier diet. It is expected to expand in 2025, by 8.3 billion to a CAGR of $8.1 \%$, which will increase by 2027 to $9.2 \%$. In Europe, an increase of USD 2.7 billion is expected by 2025 at a CAGR of $8.7 \%$. The gluten-free bakery segment (which includes bread, cookies, cakes, biscuits) is expected to witness the fastest CAGR of $10.4 \%$ in that period [48] [49].

\subsection{Nutritional Aspects of Gluten-Free Products}

The gluten-free diet requires the complete elimination of all foods that contain gluten-generating cereals or their derivatives. Therefore, pasta, bread and all

\section{Billions, USD}

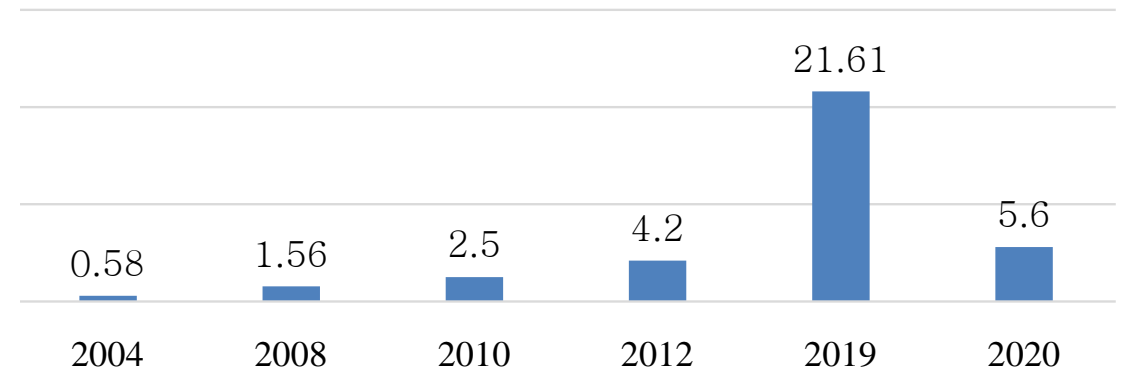

Figure 5. Evolution of the gluten-free products market [48] [49]. 
traditional flour products (wheat varieties, camut, faro, spelled, wheat malt) should be avoided, which will be replaced with gluten-free products (Table 3 ).

Opinions on the membership of oats and oat derivatives in the category of gluten-free cereals are contradictory, so the International Celiac Association (IAC) recommends the use of other cereals, which do not present risks of gluten contamination during cultivation and/or processing. Sorghum, also due to the large number of hybrids, could also present risks of gluten contamination. Rice, corn, potatoes have over the years been the most used raw materials in the diet of people intolerant to gluten, and in recent years new possibilities have focused the attention of nutritionists such as cereals, pseudo-cereals and legumes. There are no restrictions on vegetables, fruits, meat, fish, eggs, milk and dairy products. It should be noted, however, that these gluten-free products may contain gluten in the commercially available finished product due to cross-contamination.

Gluten proteins are not essential for human nutrition, but the percentage distribution of gluten-generating protein fractions directly influences the technological properties of products [15] [52]. Nutritionally, the biological value of gluten is modest, being poor in some essential amino acids. The absence of this compound in the diet does not bring any specific nutritional risk, especially in the first years of life, but guarantees a major palatability of the products.

Otherwise, the guidelines for proper nutrition are valid. It is fundamental to focus not only on the nutritional aspects of each food, but to consider the more general aspects such as: the correct distribution of meals per day, avoiding food excesses or abuses. Fresh and seasonal products are always favored, including their diversification, as far as possible, to the extent that they cover the daily nutritional needs [36] [41] [53].

\subsubsection{Gluten and Its Importance}

First isolated in 1725 by the Italian chemist Giacomo Beccari, gluten is the main protein fraction in wheat and other cereals and is made up of glutenin and prolamine [54]. Both gliadin and glutenin comprise numerous protein components, characterized by minimal structural compositional differences (micro heterogeneity) [55] [56]. In aqueous solution, bonds are formed between gliadin and

Table 3. Cereals allowed and prohibited in the diet of people with gluten-related disorders [51].

\begin{tabular}{ccc}
\hline Permits & Controversial & Prohibited \\
\hline & & Wheat (Triticum aestivum) \\
Rye (Rye cereal) \\
Rice & Barley (Hordenum vulgare) \\
Maize & Oats Sorghum & Triticale (the result of crossing rye and wheat) \\
Millet & Boulgour (wheat ripe in the Middle East) \\
Buckwheat & Cous-Cous (produced from durum wheat semolina, of Arab origin) \\
Amaranth & Frik or Kamut (Egyptian wheat) \\
& Spelta (spelled wheat variety) \\
& & Seitan (derived from wheat gluten (in the East) \\
\hline
\end{tabular}


glutenin, which lead to the formation of a three-dimensional protein reticulum, which gives elasticity and resistance to the spread of the dough.

Starches of flour and gas remain in the gluten network, which support the dough during fermentation. These properties justify the primary role of gluten in the manufacture of bakery products. A sufficiently elastic and extensible gluten ensures the obtaining of well-developed bread, with fine, uniform porosity and thin pore walls. However, an excessively resistant and extensible gluten leads to poorly developed products, with a dense core and, respectively, to flat products, with coarse porosity [57]. Gliadin controls the extensibility and volume of the bread, and glutenins are responsible for the elasticity of the dough and its kneading conditions [58] [59]. The properties of gluten are determined by the tertiary and quaternary structure of proteins, the primary and secondary structure having a smaller role. There is a correlation between the rheological properties of the dough and the content of -S and -SS- groups. As the strength of the flour increases, the content of -SS- groups increases and that of -SH decreases. For a -SS -/-SH ratio of 15/19 a maximum volume of bread/bakery products is obtained. The volume of bread increases with increasing protein content of flour, but depends on their quality [58] [59].

\subsubsection{Characteristics of Bakery Products without Gluten}

Gluten-free bakery products differ significantly from standard wheat flour products. Although the technological process of obtaining them, as a rule, includes the same general steps, the time and conditions of product development vary considerably. In gluten-free bread, gluten-free bread is balanced by complex formulas, based on gluten-free flours and starches, including hydrocolloids, in order to reproduce the viscoelastic properties of wheat flour dough [60] [61].

However, gluten-free bakery products usually have inferior characteristics to those made from wheat flour. The lack of a resistant protein matrix, able to expand and retain gases, conditions the formation of weak doughs, with high permeability to carbon dioxide and great difficulties in maintaining the structure, which leads to a reduction in baking volume [62]. The absence of gluten also affects the ability to retain water in bread, which demonstrates an early friable structure and rapid rancidity of the core. In addition, due to the inclusion of starch in recipes and the short mixing and fermentation time, gluten-free bakery products have a pale color and a pronounced weak taste [63].

Marketed gluten-free bread is usually produced from starch and is therefore low in fiber, vitamins and nutrients, which worsen the already nutritionally unbalanced diet of people with celiac disease [64]. Schober (2005) [65] classifies gluten-free bread into two types:

- based on starches;

- based on cereal flour.

The range of cereals used in the formulation of gluten-free bakery products is quite varied. Technologies for obtaining gluten-free and without protein bread from buckwheat flour, rice and corn and based on corn and potato starch, yeast 
and sugar have been developed and studied [66]. The use of starch in bread recipes (based on starch) has been mentioned in many studies. However, to date there is no standardized baking method for starch-based bakery products or for those based on gluten-free cereal flour [67] [68].

\subsection{Deficiencies of Gluten Free Products}

Although considerable progress has been made in the development of gluten-free products, their limited quality and rapid aging are a problem. As the niche for these products on the market is still small, their rotation is very low, so inevitably there is a need to create gluten-free products with a longer shelf life. This is difficult to achieve, especially for bread and bakery products, due to the inherent characteristics of the products. Therefore, in many cases, the quality of gluten-free products is not acceptable when they reach celiac people. In addition, gluten, free products are more expensive than their wheat counterparts [69] [70]. Most gluten-free products are limited in nutrients and can carry risks if not detected in time and treated properly [2]. Some studies have shown that GF products have a low caloric and protein intake, dietary fiber deficiencies, vitamins (D, riboflavin, niacin, folic acid (B9) B12, K), and some minerals (Fe, Ca, Mg, Zn) [71] [72]. Often these products, probably due to its technological peculiarities, contain excessive amounts of lipids, hydrogenated fatty acids, phosphorus etc.

(Table 4).

Table 4. Nutritional deficiencies of Gluten-free products.

\begin{tabular}{|c|c|c|c|}
\hline Authors & $\begin{array}{l}\text { Publication } \\
\text { of the paper }\end{array}$ & Deficiencies & Excesses \\
\hline$[2]$ & 2019 & Protein, fiber, $\mathrm{Ca}, \mathrm{Fe}$, niacin, thiamine & \\
\hline [41] & 2019 & $\begin{array}{l}\text { In particular folate, } \mathrm{Mg}, \mathrm{Zn} \text {, products with GI increased excess } \\
\text { lipids }\end{array}$ & $\begin{array}{l}\text { Recommendations: food education, consumption of } \\
\text { local fortified products, pseudo-cereals etc. }\end{array}$ \\
\hline [30] & 2010 & Fiber & \\
\hline [73] & 2018 & $\begin{array}{l}\text { Low in protein, carbohydrates, fiber, starch, ash, } \mathrm{Na}, \mathrm{Ca}, \mathrm{Fe} \text {, } \\
\text { folate and } \mathrm{B} 12 .\end{array}$ & $\begin{array}{l}\mathrm{Na}, \mathrm{Ca}, \mathrm{P} . \\
\text { Higher content of niacin, riboflavin }\end{array}$ \\
\hline [74] & 2019 & $\begin{array}{l}\text { Fe, pyridoxine, riboflavin, thiamine, niacin, folation, } \\
\text { manganese, B5. }\end{array}$ & \\
\hline [41] & 2019 & $\mathrm{Fe}$, vit $\mathrm{D}$, fiber, Ca. Particularly folate, $\mathrm{Mg}, \mathrm{Zn}$, & Lipids, products with increased GI \\
\hline [75] & 2019 & $\begin{array}{l}\text { Like, } \mathrm{Fe}, \mathrm{Mg}, \mathrm{Zn}, \mathrm{B} 12 \text {, folate, vitamin } \mathrm{D} \text {, fiber. Risk of } \\
\text { constipation }\end{array}$ & $\begin{array}{l}\text { Higher content of As, hydrogenated and saturated fatty } \\
\text { acids and a higher GI }\end{array}$ \\
\hline [76] & 2019 & $\begin{array}{l}\text { Menu Caloric Deficiency, 36\%, Fiber, Ca, Mg, Vitamin D, E, } \\
\mathrm{Na}, \mathrm{Fe}, \mathrm{Zn} \text {, Thiamine }\end{array}$ & \\
\hline [69] & 2019 & Gluten free foods contaminated with gluten! & \\
\hline [43] & 2018 & $\mathrm{Ca}, \mathrm{Fe}, \mathrm{Mg}$ și $\mathrm{Zn}$ & \\
\hline [77] & 2018 & $\begin{array}{l}\text { GF flours, exempt from British legislation on micronutrient } \\
\text { fortification. GF-products richer in fat and fiber. }\end{array}$ & \\
\hline [78] & 2017 & Mineral elements & $\begin{array}{l}\text { Lack of nutritional information about these minerals on } \\
\text { the product label }\end{array}$ \\
\hline
\end{tabular}




\section{Continued}

\begin{tabular}{|c|c|c|c|}
\hline$[70]$ & 2016 & $\begin{array}{l}\text { In bakery products, Canadian bread: protein deficiencies, Fe. } \\
\text { In pasta: low iron content, folate, fiber. }\end{array}$ & $\begin{array}{l}\text { Increased fat content (in the same products). } \\
\text { Pasta richer in carbohydrates }\end{array}$ \\
\hline [79] & 2016 & $\mathrm{Ca}$, vit $\mathrm{D}$. & \\
\hline$[80]$ & 2016 & & $\begin{array}{l}\text { Remark: a transition from a suspicion about "special } \\
\text { diet" management to an appropriate and responsible } \\
\text { management of meals for children and young people } \\
\text { suffering from this specific condition (in GF food } \\
\text { school services). }\end{array}$ \\
\hline [81] & 2016 & Fiber deficiency, vit. D, B12, folate, $\mathrm{Zn}, \mathrm{Mg}$, Ca & Saturated and hydrogenated fatty acids \\
\hline [32] & 2015 & Folic acid & \\
\hline [45] & 2015 & $\mathrm{Fe}$ & \\
\hline [34] & 2015 & Protein & \\
\hline [82] & 2014 & Saturated fatty acids, vitamin D. & Monounsaturated fatty acids, phosphorus \\
\hline [36] & 2014 & Caloric deficiencies, fiber, & \\
\hline [35] & 2014 & Vit. A, B6, Zn, Fe. & \\
\hline [46] & 2011 & Fe, vit. B12, D & \\
\hline [30] & 2010 & $\begin{array}{l}\text { Fe, folate, } \mathrm{Ca}, \mathrm{P} \text {, vitamin } \mathrm{D} \text {, fiber, thiamine, niacin and } \\
\text { riboflavin }\end{array}$ & \\
\hline
\end{tabular}

Some GF products marketed lack detailed information on the nutritional value on the label [43]: mineral content, vitamins. Gluten-contaminated GF-branded products have also been identified [69] (gluten content exceeds $20 \mathrm{ppm}$ ), which poses risks to people with gluten-related disorders. Researchers in the field are largely unanimous about the impact of GFD on quality of life, and the recommendations involve: Researchers in the field are largely unanimous about the impact of GFD on quality of life, and the recommendations involve:

- Direct assessment of the nutritional quality of GF products and identification of deficiencies [2] [81];

- Development of educational strategies focused on the relationship between nutrients, food and human health, optimization of services etc [36] [75] [81] [82] [80];

- Diversification of the food ration by including in the menus pseudocereals, legumes, natural products rich in calcium, iron, fiber, folate [32] [41] [78];

- Extension of fortification legislation for GF flour products [77];

- Counseling and psychological support can also improve diet compliance [32].

According to some authors, the adoption of a GFD requires, at the initial stage, an increase in protein intake to 140 - $160 \mathrm{~g} /$ day (meat, fish, cheese, legumes, eggs) and a quantitative reduction of carbohydrates to $200 \mathrm{~g} /$ day. The recommended amount of lipids (vegetable and animal) should not exceed 100 g/day. The energy value of the gluten-free diet should be 2300 - $3337 \mathrm{kcal}$ [83]. Carbohydrate intake may be increased to $400 \mathrm{~g} /$ day with normalization of the intestinal epithelium. Limit products that stimulate the secretion of gastric juice 
and products that can affect the liver. 10 years ago, there was talk of a gluten-free diet focused mainly on safety, referring to the level of gluten (values below 20 $\mathrm{ppm} / \mathrm{kg}$ produced) in celiac products. In the following years, the concept of product quality also adhered to the safety concept: organoleptic, technological and nutritional. Today, in particular, it focuses on personalized nutrition and nutritional quality: the composition and ratio of macro- and micronutrients in dietary products.

\section{Conclusions}

Numerous studies have reported that celiac disease has a major impact on the nutritional status of celiac disease at the time of diagnosis and in the pre-diagnosis period. People with gluten-related disorders often have nutrient deficiencies, but they are not always correlated with GFD. However, nutritional therapy is the only treatment for celiac disease unanimously accepted by the medical community and must be strict and followed for life, especially in celiac disease. In the perspective of recent research in the field of GF product development, it is gratifying that the concept of safety has adhered to the concept of quality: organoleptic, technological and nutritional. Today, in particular, we focus on nutritional quality: the composition, ratio and association of macro- and micronutrients in dietary products. Specialists in the field are unanimous in the opinion that increasing nutritional security and ensuring sustainability can be ensured by:

- diversification of GF regimes with local products: inclusion in menus of pseudo-cereals, legumes, natural local products rich in calcium, iron, fiber, folate etc.;

- by extending legislation to strengthen gluten-free products; developing educational strategies focused on the relationship between nutrients, food and human health;

- informing the population and optimizing services in order to increase the quality of life and health etc.

However, the design of GF products, both technologically and nutritionally, especially bakery/pastry, pasta is still a challenge, and research in this area is current and required.

\section{Funding}

The research was funded by State Project 20.80009.5107.10, nr. PS-62 "Personalized nutrition and intelligent technologies for my well-being", running at Technical University of Moldova.

\section{Conflicts of Interest}

The authors declare no conflict of interest.

\section{References}

[1] FAO (2020) Cereal Markets to Remain Well Supplied in 2020/21. 
http://www.fao.org/worldfoodsituation/csdb/en

[2] Lerner, A., O’Bryan, T. and Matthias, T. (2019) Navigating the Gluten-Free Boom: The Dark Side of Gluten Free Diet. Frontiers in Pediatrics, 7, 414. https://doi.org/10.3389/fped.2019.00414

[3] Sapone, A., Bai, J.C., Ciacci, C., et al. (2012) Spectrum of Gluten-Related Disorders: Consensus on New Nomenclature and Classification. BMC Medicine, 10, 13. https://doi.org/10.1186/1741-7015-10-13

[4] Békés, F., Schoenlechner, R. and Tömösközi, S. (2017) Ancient Wheats and Pseudocereals for Possible Use in Cereal-Grain Dietary Intolerances. In: Cereal Grains, Elsevier, Amsterdam, 353-389. https://doi.org/10.1016/B978-0-08-100719-8.00014-0

[5] Volta, U. and Ubaldi, E. (2010) La malattia celiaca in medicina generale/Celiac Disease in General Medicine. Pacini Editore, Ospedaletto (Pisa).

[6] Direzione Generale della Sicurezza degli Alimenti e della Nutrizione (2011) Annual Report to Parliament on Celiac Disease (Relazione annuale al Parlamento sulla celiachia).

[7] Direzione Generale per l'Igiene e la Sicurezza degli Alimenti e la Nutrizione (2013) Annual Report to Parliament on Celiac Disease (Relazione annuale al Parlamento sulla celiachia).

[8] Fasano, A., Berti, I., Gerarduzzi, T., et al. (2003) Prevalence of Celiac Disease in At-Risk and Not-at-Risk Groups in the United States: A Large Multicenter Study. Archives of Internal Medicine, 163, 286. https://doi.org/10.1001/archinte.163.3.286

[9] Irvine, A.J., Chey, W.D. and Ford, A.C. (2017) Screening for Celiac Disease in Irritable Bowel Syndrome: An Updated Systematic Review and Meta-Analysis. American Journal of Gastroenterology, 112, 65-76. https://doi.org/10.1038/ajg.2016.466

[10] Sapone, A., Lammers, K.M., Casolaro, V., et al. (2011) Divergence of Gut Permeability and Mucosal Immune Gene Expression in Two Gluten-Associated Conditions: Celiac Disease and Gluten Sensitivity. BMC Medicine, 9, 23. https://doi.org/10.1186/1741-7015-9-23

[11] (2020) Global Celiac Disease (CD) Market Insights, Epidemiology and Market Forecasts, 2017-2019 \& 2020-2030. GlobelNewswire.

https://www.globenewswire.com/news-release/2020/09/28/2099717/0/en/Global-Cel iac-Disease-CD-Market-Insights-Epidemiology-and-Market-Forecasts-2017-2019-2 $\underline{020-2030 . h t m l}$

[12] Direzione Generale per l'Igiene e la Sicurezza, degli Alimenti e la Nutrizione (2018) Annual Report to Parliament on Celiac Disease (Relazione annuale al Parlamento sulla celiachia).

[13] Zugravu, C. (2020) Celiac Disease, General Aspects and Therapeutic Advances (Boala celiaca, aspecte generale si progrese terapeutice). Galenus.

[14] Kilmartin, C., Wieser, H., Abuzakouk, M., et al. (2006) Intestinal T Cell Responses to Cereal Proteins in Celiac Disease. Digestive Diseases and Sciences, 51, 202-209. https://doi.org/10.1007/s10620-006-3108-0

[15] Kagnoff, M.F. (2005) Overview and Pathogenesis of Celiac Disease. Gastroenterology, 128, S10-S18. https://doi.org/10.1053/j.gastro.2005.02.008

[16] Matysiak-Budnik, T., Candalh, C., Dugave, C., et al. (2003) Alterations of the Intestinal Transport and Processing of Gliadin Peptides in Celiac Disease. Gastroenterology, 125, 696-707. https://doi.org/10.1016/S0016-5085(03)01049-7

[17] Mcl Mowat, A. (2003) Coeliac Disease-A Meeting Point for Genetics, Immunology, and Protein Chemistry. The Lancet, 361, 1290-1292. 
https://doi.org/10.1016/S0140-6736(03)12989-3

[18] Qi, P.F., Wei, Y.M., Yue, Y.W., et al. (2006) Biochemical and Molecular Characterization of Gliadins. Molecular Biology (Mosk), 40, 796-807.

https://doi.org/10.1134/S0026893306050050

[19] Koehler, P., Wieser, H. and Konitzer, K. (2014) Gluten-The Precipitating Factor. In: Celiac Disease and Gluten, Elsevier, Amsterdam, 97-148. https://doi.org/10.1016/B978-0-12-420220-7.00002-X

[20] Maiuri, L., Ciacci, C., Ricciardelli, I., et al. (2003) Association between Innate Response to Gliadin and Activation of Pathogenic T Cells in Coeliac Disease. The Lancet, 362, 30-37. https://doi.org/10.1016/S0140-6736(03)13803-2

[21] Dunne, M.R., Byrne, G., Chirdo, F.G. and Feighery, C. (2020) Coeliac Disease Pathogenesis: The Uncertainties of a Well-Known Immune Mediated Disorder. Frontiers in Immunology, 11, 1374. https://doi.org/10.3389/fimmu.2020.01374

[22] Inomata, N. (2009) Wheat Allergy. Current Opinion in Allergy and Clinical Immunology, 9, 238-243. https://doi.org/10.1097/ACI.0b013e32832aa5bc

[23] Ward, R.K. (2015) Introduction to Food Allergy. In: Handbook of Food Allergen Detection and Control, Elsevier, Amsterdam, 1-15. https://doi.org/10.1533/9781782420217.1

[24] Pietzak, M. (2012) Celiac Disease, Wheat Allergy, and Gluten Sensitivity: When Gluten Free Is Not a Fad. JPEN Journal of Parenteral and Enteral Nutrition, 36, 68S-75S. https://doi.org/10.1177/0148607111426276

[25] Fasano, A., Sapone, A., Zevallos, V. and Schuppan, D. (2015) Nonceliac Gluten Sensitivity. Gastroenterology, 148, 1195-1204.

https://doi.org/10.1053/j.gastro.2014.12.049

[26] Soliman, A.T., Laham, M., Jour, C., et al. (2019) Linear Growth of Children with Celiac Disease after the First Two Years on Gluten-Free Diet: A Controlled Study. Acta Biomedica, 90, 20-27.

[27] Green, P.H.R., Rostami, K. and Marsh, M.N. (2005) Diagnosis of Coeliac Disease. Best Practice \& Research Clinical Gastroenterology, 19, 389-400. https://doi.org/10.1016/j.bpg.2005.02.006

[28] See, J. and Murray, J.A. (2006) Gluten-Free Diet: The Medical and Nutrition Management of Celiac Disease. Nutrition in Clinical Practice, 21, 1-15. https://doi.org/10.1177/011542650602100101

[29] Annibale, B., Severi, C., Chistolini, A., et al. (2001) Efficacy of Gluten-Free Diet Alone on Recovery from Iron Deficiency Anemia in Adult Celiac Patients. American Journal of Gastroenterology, 96, 132-137. https://doi.org/10.1111/j.1572-0241.2001.03463.x

[30] Saturni, L., Ferretti, G. and Bacchetti, T. (2010) The Gluten-Free Diet: Safety and Nutritional Quality. Nutrients, 2, 16-34. https://doi.org/10.3390/nu2010016

[31] Barton, S.H., Kelly, D.G. and Murray, J.A. (2007) Nutritional Deficiencies in Celiac Disease. Gastroenterology Clinics of North America, 36, 93-108.

https://doi.org/10.1016/j.gtc.2007.01.006

[32] Abenavoli, L., Delibasic, M., Peta, V., et al. (2015) Nutritional Profile of Adult Patients with Celiac Disease. European Review for Medical and Pharmacological Sciences, 19, 4285-4292.

[33] Burger, J.P.W., van der Laan, J.J.H., Jansen, T.A., et al. (2018) Low Yield for Routine Laboratory Checks in Follow-Up of Coeliac Disease. Journal of Gastrointestinal and Liver Diseases, 27, 233-239. https://doi.org/10.15403/gld.2014.1121.273.jph 
[34] van Hees, N.J.M., Giltay, E.J., Tielemans, S.M.A.J., et al. (2015) Essential Amino Acids in the Gluten-Free Diet and Serum in Relation to Depression in Patients with Celiac Disease. PLOS ONE, 10, e0122619. https://doi.org/10.1371/journal.pone.0122619

[35] Wierdsma, N., van Bokhorst-de van der Schueren, M., Berkenpas, M., et al. (2013) Vitamin and Mineral Deficiencies Are Highly Prevalent in Newly Diagnosed Celiac Disease Patients. Nutrients, 5, 3975-3992. https://doi.org/10.3390/nu5103975

[36] Miranda, J., Lasa, A., Bustamante, M.A., et al. (2014) Nutritional Differences between a Gluten-Free Diet and a Diet Containing Equivalent Products with Gluten. Plant Foods for Human Nutrition, 69, 182-187. https://doi.org/10.1007/s11130-014-0410-4

[37] Stefanelli, G., Viscido, A., Longo, S., et al. (2020) Persistent Iron Deficiency Anemia in Patients with Celiac Disease Despite a Gluten-Free Diet. Nutrients, 12, 2176. https://doi.org/10.3390/nu12082176

[38] Martín-Masot, Nestares, Diaz-Castro, et al. (2019) Multifactorial Etiology of Anemia in Celiac Disease and Effect of Gluten-Free Diet: A Comprehensive Review. Nutrients, 11, 2557. https://doi.org/10.3390/nu11112557

[39] Pinto-Sanchez, M.I. and Bai, J.C. (2019) Toward New Paradigms in the Follow Up of Adult Patients with Celiac Disease on a Gluten-Free Diet. Frontiers in Nutrition, 6, 153. https://doi.org/10.3389/fnut.2019.00153

[40] Fernández, C.B., et al. (2019) Nutritional Status in Spanish Children and Adolescents with Celiac Disease on a Gluten Free Diet Compared to Non-Celiac Disease Controls. Nutrients, 11, 2329. https://doi.org/10.3390/nu11102329

[41] Nardo, G.D., Villa, M.P., Conti, L., et al. (2019) Nutritional Deficiencies in Children with Celiac Disease Resulting from a Gluten-Free Diet: A Systematic Review. $\mathrm{Nu}$ trients, 11, 1588. https://doi.org/10.3390/nu11071588

[42] Rondanelli, Faliva, Gasparri, et al. (2019) Micronutrients Dietary Supplementation Advices for Celiac Patients on Long-Term Gluten-Free Diet with Good Compliance: A Review. Medicina, 55, 337. https://doi.org/10.3390/medicina55070337

[43] Rybicka, I. (2018) The Handbook of Minerals on a Gluten-Free Diet. Nutrients, 10, 1683. https://doi.org/10.3390/nu10111683

[44] Aballay, L.R. (2017) Niveles de hierro en sangre según adherencia a la dieta libre de gluten en niños celíacos de edad de escolar. Nutricion Hospitalaria, 35, 1-248. https://doi.org/10.20960/nh.919

[45] Freeman, H.J. (2015) Iron Deficiency Anemia in Celiac Disease. World Journal of Gastroenterology: WJG, 21, 9233. https://doi.org/10.3748/wjg.v21.i31.9233

[46] Vilppula, A., Kaukinen, K., Luostarinen, L., et al. (2011) Clinical Benefit of Gluten-Free Diet in Screen-Detected Older Celiac Disease Patients. BMC Gastroenterology, 11, 136. https://doi.org/10.1186/1471-230X-11-136

[47] Rodrigo-Sáez, L., Fuentes-Álvarez, D., Pérez-Martínez, I., et al. (2011) Refractory Iron-Deficiency Anemia and Gluten Intolerance: Response to Gluten-Free Diet. Revista Espanola de Enfermedades Digestives, 103, 349-354.

https://doi.org/10.4321/S1130-01082011000700003

[48] (2020) Gluten-Free Products Market Size, Share \& Trends Analysis Report by Product (Bakery Products, Dairy/Dairy Alternatives), by Distribution Channel (Grocery Stores, Mass Merchandiser), by Region, and Segment Forecasts, 2020-2027. Grand View Research.

https://www.grandviewresearch.com/industry-analysis/gluten-free-products-market 
[49] (2020) Gluten-Free Products Market by Type (Bakery Products, Snacks \& RTE Products, Condiments \& Dressings, Pizzas \& Pastas), Distribution Channel (Conventional Stores, Specialty Stores and Drugstores \& Pharmacies), Form \& Region-Global Forecast to 2025. Markets and Markets.

https://www.marketsandmarkets.com/Market-Reports/gluten-free-products-market $\underline{-738 . h t m l}$

[50] Siminiuc, R. and Țurcanu, D. (2020) The Impact of the Pandemic on the Agri-Food System.

[51] Comino, I., de Lourdes Moreno, M., Real, A., et al. (2013) The Gluten-Free Diet: Testing Alternative Cereals Tolerated by Celiac Patients. Nutrients, 5, 4250-4268. https://doi.org/10.3390/nu5104250

[52] Rodica, S., Lidia, C., Liliana, P. and Viorica, B. (2012) The Effect of Dehulling and Thermal Treatment on the Protein Fractions in Soryz (Sorghum oryzoidum) Grains. Fascicle VI: Food Technology, 36, 97-102.

[53] Siminiuc, R. and Țurcanu, D. (2020) The Impact of Hydrothermal Treatments on Technological Properties of Whole Grains and Soriz (Sorghum oryzoidum) Groats. FNS, 11, 955-968. https://doi.org/10.4236/fns.2020.1110067

[54] Spary, E.C. and Klein, U. (2010) Materials and Expertise in Early Modern Europe: Between Market and Laboratory. University of Chicago Press, Chicago, London. https://doi.org/10.7208/chicago/9780226439709.001.0001

[55] Figoni, P. (2011) How Baking Works: Exploring the Fundamentals of Baking Science. 3rd Edition, John Wiley \& Sons, Hoboken.

[56] Tronsmo, K.M., Færgestad, E.M., Longva, Å., et al. (2002) A Study of How Size Distribution of Gluten Proteins, Surface Properties of Gluten and Dough Mixing Properties Relate to Baking Properties of Wheat Flours. Journal of Cereal Science, 35, 201-214. https://doi.org/10.1006/jcrs.2001.0431

[57] Cabras, P. and Martelli, A. (2004) Food Chemistry: Nutrients, Foods of Plant Origin, Foods of Animal Origin, Food Supplements, Beverages, Undesirable Substances/Chimica degli alimenti: Nutrienti, alimenti di origine vegetale, alimenti di origine animale, integratori alimentari, bevande, sostenanze indesiderabili. Piccin, Padova.

[58] Gujral, H.S. and Rosell, C.M. (2004) Functionality of Rice Flour Modified with a Microbial Transglutaminase. Journal of Cereal Science, 39, 225-230. https://doi.org/10.1016/j.jcs.2003.10.004

[59] Vaccarini, G. (2016) Pairing Manual/Manuale degli abbinamenti: Armonie del gusto, ideali contrasti fra vino e cibo. Giunti, Firenze; Milano.

[60] Wang, K., Lu, F., Li, Z., et al. (2017) Recent Developments in Gluten-Free Bread Baking Approaches: A Review. Food Science and Technology, 37, 1-9. https://doi.org/10.1590/1678-457x.01417

[61] Cappelli, A., Oliva, N. and Cini, E. (2020) A Systematic Review of Gluten-Free Dough and Bread: Dough Rheology, Bread Characteristics, and Improvement Strategies. Applied Sciences, 10, 6559. https://doi.org/10.3390/app10186559

[62] Steadman, K.J., Burgoon, M.S., Lewis, B.A., et al. (2001) Buckwheat Seed Milling Fractions: Description, Macronutrient Composition and Dietary Fibre. Journal of Cereal Science, 33, 271-278. https://doi.org/10.1006/jcrs.2001.0366

[63] Hui, Y.H. (2007) Handbook of Food Products Manufacturing. Wiley-Interscience, Hoboken. https://doi.org/10.1002/0470113553

[64] Mariani, P., Viti, M.G., Montouri, M., et al. (1998) The Gluten-Free Diet: A Nutri- 
tional Risk Factor for Adolescents with Celiac Disease? Journal of Pediatric Gastroenterology \& Nutrition, 27, 519-523.

https://doi.org/10.1097/00005176-199811000-00004

[65] Schober, T.J., Messerschmidt, M., Bean, S.R., et al. (2005) Gluten-Free Bread from Sorghum: Quality Differences among Hybrids. Cereal Chemistry Journal, 82, 394-404. https://doi.org/10.1094/CC-82-0394

[66] Belderok, B. (2000) [No Title Found]. Plant Foods for Human Nutrition, 55, 1-14. https://doi.org/10.1023/A:1008199314267

[67] Demiate, I.M., Dupuy, N., Huvenne, J.P., et al. (2000) Relationship between Baking Behavior of Modified Cassava Starches and Starch Chemical Structure Determined by FTIR Spectroscopy. Carbohydrate Polymers, 42, 149-158. https://doi.org/10.1016/S0144-8617(99)00152-6

[68] Gallagher, E., Gormley, T.R. and Arendt, E.K. (2003) Crust and Crumb Characteristics of Gluten Free Breads. Journal of Food Engineering, 56, 153-161. https://doi.org/10.1016/S0260-8774(02)00244-3

[69] Paul, S., Stanton, L., Adams, H. and Basude, D. (2019) Coeliac Disease in Children: The Need to Improve Awareness in Resource-Limited Settings. Sudanese Journal of Paediatrics, 19, 6-13. https://doi.org/10.24911/SJP.106-1549488256

[70] Cialdella-Kam, L., Kulpins, D. and Manore, M.M. (2016) Vegetarian, Gluten-Free, and Energy Restricted Diets in Female Athletes. Sports (Basel), 4, 50. https://doi.org/10.3390/sports 4040050

[71] Bardella, M.T., Fredella, C., Prampolini, L., et al. (2000) Body Composition and Dietary Intakes in Adult Celiac Disease Patients Consuming a Strict Gluten-Free Diet. The American Journal of Clinical Nutrition, 72, 937-939. https://doi.org/10.1093/ajcn/72.4.937

[72] Ciacci, C., Cirillo, M., Cavallaro, R. and Mazzacca, G. (2002) Long-Term Follow-Up of Celiac Adults on Gluten-Free Diet: Prevalence and Correlates of Intestinal Damage. Digestion, 66, 178-185. https://doi.org/10.1159/000066757

[73] Kosendiak, A., Stanikowski, P., Domagała, D. and Gustaw, W. (2020) Gluten-Free Diet in Prisons in Poland: Nutrient Contents and Implementation of Dietary Reference Intake Standards. Nutrients, 12, 2829. https://doi.org/10.3390/nu12092829

[74] Larretxi, I., Txurruka, I., Navarro, V., et al. (2019) Micronutrient Analysis of Gluten-Free Products: Their Low Content Is Not Involved in Gluten-Free Diet Imbalance in a Cohort of Celiac Children and Adolescent. Foods, 8, 321. https://doi.org/10.3390/foods8080321

[75] Diez-Sampedro, A., Olenick, M., Maltseva, T. and Flowers, M. (2019) A Gluten-Free Diet, Not an Appropriate Choice without a Medical Diagnosis. Journal of Nutrition and Metabolism, 2019, Article ID: 2438934. https://doi.org/10.1155/2019/2438934

[76] Kikut, J., Konecka, N. and Szczuko, M. (2019) Quantitative Assessment of Nutrition and Nutritional Status of Patients with Celiac Disease Aged 13-18. Roczniki Państwowego Zakładu Higieny, 70, 359-367. https://doi.org/10.32394/rpzh.2019.0084

[77] Allen, B. and Orfila, C. (2018) The Availability and Nutritional Adequacy of Gluten-Free Bread and Pasta. Nutrients, 10, 1370. https://doi.org/10.3390/nu10101370

[78] Rybicka, I. and Gliszczynska-Swiglo, A. (2017) Gluten-Free Flours from Different Raw Materials as the Source of Vitamin $\mathrm{B}_{1}, \mathrm{~B}_{2}, \mathrm{~B}_{3}$ and $\mathrm{B}_{6}$. Journal of Nutritional Science and Vitaminology, 63, 125-132. https://doi.org/10.3177/jnsv.63.125

[79] Krupa-Kozak, U. and Drabińska, N. (2016) Calcium in Gluten-Free Life: Health-Related and Nutritional Implications. Foods, 5, 51. 
https://doi.org/10.3390/foods5030051

[80] Bioletti, L., Capuano, M.T., Vietti, F., et al. (2016) Celiac Disease and School Food Service in Piedmont Region: Evaluation of Gluten-Free Meal. Annali Di Igiene: $\mathrm{Me}-$ dicinaPreventiva E Di Comunita, 28, 145-157.

[81] Vici, G., Belli, L., Biondi, M. and Polzonetti, V. (2016) Gluten Free Diet and Nutrient Deficiencies: A Review. Clinical Nutrition, 35, 1236-1241. https://doi.org/10.1016/j.clnu.2016.05.002

[82] Salazar Quero, J.C., Espín Jaime, B., Rodríguez Martínez, A., et al. (2015) Valoración nutricional de la dieta sin gluten. Es la dieta sin gluten deficitaria en algún nutriente? Anales de Pediatría, 83, 33-39. https://doi.org/10.1016/j.anpedi.2014.08.011

[83] Baranovskii, Iu.А. (Барановский, Ю. А) (2008) Dietetics (Диетология). 